Article

\title{
Insider Trading and Institutional Holdings in Seasoned Equity Offerings
}

\author{
Ching-Chih $\mathrm{Wu}^{*}$ and Tung-Hsiao Yang \\ Department of Finance, National Chung-Hsing University, Taichung City 40227, Taiwan; tyang1@nchu.edu.tw \\ * Correspondence: ccwu886@gmail.com
}

Received: 21 August 2018; Accepted: 6 September 2018; Published: 10 September 2018

check for updates

\begin{abstract}
We investigate three issues about the impact of insider trades and institutional holdings on seasoned equity offerings (SEOs). First, we test how insider trades affect the trading behavior of institutional investors in SEOs. Second, we test whose trading behavior, either insiders or institutional investors, has greater explanatory power for the performance of SEO firms after issuing new stocks. Third, we analyze the industry-wide spillover effects of insider trades and institutional holdings. Empirically, we find that insiders and institutional investors of SEO firms may utilize similar information in their transactions because insider trades induce similar trading behavior for institutional investors. In addition, insider trades, relative to institutional holdings, have greater explanatory power for SEO firm's long-term performance. Finally, compared with insider trades, institutional holdings have a more significant spillover effect in the industry of SEO firms.
\end{abstract}

Keywords: insider trade; institutional holding; spillover effect; contagion effect

\section{Introduction}

Information asymmetry exists in financial markets around the world. Some investors have information advantage relative to others and normally they would take advantage of these information sources to benefit themselves (Akerlof 1970; Chiang and Venkatesh 1988; Marquardt and Wiedman 1998; Noe 1999; Aboody and Lev 2000; Dell'Ariccia and Marquez 2004; Eleswarapu et al. 2004) ${ }^{1}$. Even though the existing evidence supports weak form or semi-strong form market efficiency, it is not uncommon to find some investors have a better investment performance than others due to the information advantage. For example, insiders and institutional investors are two types of investors that may have information advantages over other outside or retail investors (Frankel and Li 2004; Huson and MacKinnon 2003; Baik et al. 2010; Jiang 2010). In general, these two parties may share the same information sources and researchers utilize their trading behavior to forecast the firm's performance after seasoned equity offerings (SEOs) (Piotroski and Roulstone 2004; Wahal and McConnell 2000; Ferreira and Matos 2008; Aggarwal et al. 2011).

In this study, we follow the previous literature by using the SEOs to analyze the trading behavior of insiders and institutional investors (see Chemmanur et al. 2009; Griffin et al. 2012; Harjoto and Garen 2005). In addition, we also extend our research to the spillover effect of these two types of investors in the industries. (Bradley and Yuan 2013; Hameed et al. 2015; Benveniste et al. 2002; Benveniste et al. 2003; Slovin et al. 1992; Hsu et al. 2010).

There are three research questions in this study. First, we test how insider trades affect the trading behavior of institutional investors in the SEOs. Some researchers, such as Piotroski and Roulstone

1 The accounting performance is also hard to predict, such as earning or sales. de Bruijn and Franses (2018) show that the earning forecast is still unreliable. 
(2004), find that insider and institutional trading influences the firms' information environment, but how the asset prices change depends on each group's relative information advantage. In addition, Luo (2005) finds that managers of merging companies appear to extract information from the market reaction of institutional investors and later consider it in closing the deal. The author concludes that firms held by short-term institutional investors have a weaker bargaining position in acquisitions. Weaker monitoring from short-term institutional investors could allow managers to proceed with value-reducing acquisitions. In contrast, Griffin et al. (2012) cannot find supportive evidence to show that institutional investors trade on the information from investment bank connections through takeover advising, initial public offering (IPO) and SEO underwriting, or lending relationships. Therefore, there is a research gap in the information flow between insiders and institutional investors. We fill in this gap and shed light on this issue by utilizing the seasoned equity offerings and test how insider trades affect the institutional holding of these SEO firms.

Second, due to the different characteristics of information sources, we test whose trading behavior, either insiders or institutional investors, has greater explanatory power for long-term performance after SEOs. We measure the insider trades and the institutional holdings before and after the SEOs and analyze the impact of the trading behavior of both groups on the long-term performance, which is measured by buy-and-hold excess returns. This analysis contributes to the related literature of understanding the prediction power of informed traders on a firm's market performance after SEOs.

Third, we analyze the industry-wide spillover effect of insider trades and institutional holdings. In the SEOs, the insiders or institutional investors may signal some private information through their trading behaviors. How do insiders and institutional investors of other firms in the same industry react to these signals? There are two different types of the spillover effect in the literature: contagion effect and competitive effect. Some studies find contagion effect in mergers and acquisitions (M\&As), such as Song and Walkling (2000) and Shahrur and Venkateswaran (2009) who analyzed the rival firms of the target and acquiring firms respectively. Others support the competitive effect. For example, Hsu et al. (2010) analyzed the rivals of IPO firms and Erwin and Miller (1998) analyzed the rivals of firms with share repurchases. Bradley and Yuan (2013) show that rival firms react significantly positively $(0.26 \%)$ to primary SEO announcements, indicative of a competitive effect, but negatively $(-0.35 \%)$ to secondary share announcements, which is evidence of a contagion effect. Based on the existing evidence, we extend our analysis to the spillover effect of insider trades and institutional holdings on the institutional holdings of matching firms in the SEOs. The analysis helps to understand how insider trades and institutional holdings affect the reaction of institutional investors of firms in the same industry.

There are many other factors that would affect the trading behavior of insiders and institutional investors, such as macro-level conditions, or industrial and firm characteristics. In the regression analyses of the SEOs, we control these factors and focus on the previous three issues. The main contribution of the study is to comprehensively analyze the reaction of insiders and institutional investors in the seasoned equity offerings. In addition, through the analysis of spillover effect for the SEOs, we can find how insiders and institutional investors of firms in the same industry react in the SEOs.

The remainder of this paper is organized as follows. Section 2 briefly summarizes the relevant literature and develops our research hypotheses. In Section 3 we describe the methodology and data collection. Section 4 reports the results of the empirical analysis, while Section 5 concludes.

\section{Literature Review and Research Hypotheses}

Many studies have examined the trading behavior of insiders and institutional investors and both groups have information advantages relative to other outside and retail investors. There is limited research on the interaction between insiders and institutional investors. Frankel and Li (2004) find that analyst following is negatively related to the profitability of insider trades and has a negative impact on insider purchases. This implies that any process of information disclosure reduces the 
information asymmetry and further changes the trading behavior of informed traders. Based on the result, we suspect that informed traders, including insiders and institutional investors, adjust their stock holdings in the SEOs once they observe the other group's move.

Piotroski and Roulstone (2004) test how much firm-specific, market-level, and industry-level information is impounded into the firm's stock price. In their research, they find that different informed participants change the information environment and the stock price reflects different information conveyed by different participants. In addition, Griffin et al. (2012) show neither brokerage house clients nor the brokerage houses themselves trade on inside information through the brokerage house associated with the information of M\&As, IPOs, and SEOs. From their results, we are interested in testing how the different informed investors change their holdings after observing the trading of other informed investors.

In contrast, Bodnaruk et al. (2009) find that funds affiliated with takeover bidder advisors take positions in target firms before the announcement. Jegadeesh and Tang (2010) also find profitable trading through target advisors. Therefore, we expect that institutional investors may utilize information from insiders by observing insider trading behavior. We test how the insider trades affect institutional holdings after SEOs. The first research hypothesis is as follows.

Hypothesis 1. Insider trading should have a substantial impact on institutional holdings after SEOs. Therefore, the trading behavior of insiders and institutional investors should be very similar around SEOs.

The existing literature shows that insiders and institutional investors play an important role in the firm's strategic decision. For example, Wahal and McConnell (2000) find a positive relation between industry-adjusted expenditures for property, plant, and equipment (PP\&E) and research and development (R\&D) and the fraction of shares owned by institutional investors. In addition, the informed traders may also utilize their information advantage to benefit themselves in their trading. Baik et al. (2010) find that both the level of and change in local institutional ownership predict future stock returns, particularly for firms with high information asymmetry. Gaspar et al. (2005) also show that both target firms and acquiring firms with short-term institutional investors have worse merging benefits relative to those with long-term institutional investors.

As per insiders, Darrough and Rangan (2005) document a positive association between discretionary current accruals in the offering year and managerial selling, suggesting that selling managers manipulate accruals. Therefore, we expect that both insider trading and the change in institutional holdings have certain explanatory power for the firm's performance. The unanswered question is which groups of investors has greater explanatory power than the other. This is our second research question and we construct the second research hypothesis based on it as follows.

Hypothesis 2. Insider trades and institutional investors have significant explanatory power for the firm's performance after the SEOs.

An SEO is a crucial corporate event and, therefore, the firm conveys certain important information to the public. Before or after the announcement the firm's insiders and institutional investors may adjust their holdings based on their perception of this event. The counterparties of the non-SEO firms may also adjust their position on the Non-SEO firms to reflect their perception of the effect of this event on the non-SEO firms. This is the spillover effect of the trading behavior of insiders and institutional investors. The spillover effect exists in many different aspects, such as merger waves (Harford 2005), new equity offerings (Benveniste et al. 2002; Benveniste et al. 2003), fraudulent financial reporting (Beatty et al. 2013), or accounting restatements (Gleason et al. 2008).

There are two competing hypotheses about the spillover effect: contagion effect and competitive effect. The 'contagion effect' implies that rival firms would have a similar response to the information with the event firms. For example, Jorion and Zhang (2007) find strong intra-industry contagion effects in the event of filing Chapter 11 bankruptcies. In contrast, the 'competitive effect' suggests that the 
rival firms would have the opposite effect on the news. For instance, Erwin and Miller (1998) show that open market repurchase announcements have a negative effect on rivals in the same industry with the event firms. Jorion and Zhang (2007) find strong intra-industry competition effects in the event of filing Chapter 7 bankruptcies. In sum, different corporate events may show a different type of spillover effect, and sometimes both effects may exist simultaneously.

Our research contributes to the related literature by analyzing the spillover effect of insider trading and the changes in institutional holdings between SEO firms and non-SEO firms. To the best of our knowledge, this is the first paper to analyze the spillover effect comprehensively in the SEOs. We construct their research hypothesis as follows:

Hypothesis 3. There exists spillover effect of insider trading and institutional holdings of SEO firms on non-SEO firms in the same industry.

\section{Methodology and Data Collection}

\subsection{Sample Selection and Variables}

We need to collect the sample firms of SEOs in this research. All these samples are in the Thomson Financial Securities Data Corporation (SDC) New Issue database and we collect a sample covering the period from 1990 to 2010 and trace their returns up to 2013. The event firm's CUSIP can be matched with the Center for Research in Securities Prices (CRSP) data. To test SEOs, we collect the sample firms based on this event. To be included in our sample, the observations must meet the following criteria:

1. The SEOs must be of common stocks of firms (share codes 10 and 11) listed on NYSE, AMEX, and NASDAQ. American depository receipts (ADRs), real estate investment trusts (REITs), closed-end mutual funds, and partnership are eliminated from the sample.

2. We exclude non-underwritten offerings, rights offerings, standby offerings, shelf offerings, pure secondary offerings, and unit offerings (equity issue with warrants). In addition, SEOs with an offer price below $\$ 5$ are dropped since many of them involve price manipulation (See Yang et al. 2016, and Hsu et al. 2016).

3. As in other previous studies, we exclude SEOs of the financial and regulated utility industries (SIC codes 6000-6999 and 4900-4999 respectively) since firms in these industries have to meet regulatory requirements in making the strategic decisions. Also, accounting items of these two industries are distinct from those of other industries.

4. A firm included in the M\&As and stock splits events type of sample cannot be in the SEOs type within the three years before and after the corporate event since the long-run performance may arise from the M\&As and stock splits events rather than the SEO event of the sampling.

We collect daily returns and number of shares outstanding of the sample firms and daily market indices (CRSP VW and EW) from the CRSP database. Annual accounting data of firm-specific variables are collected from the Compustat database. We collect monthly insider trading data from the Thomson CDA Investment database, and quarterly institutional equity holdings from the Thomson CDA Spectrum database, which are from institutional investors' 13-f filings. We use the institutional codes in the CDA Spectrum database to identify the types of the institutional investors. ${ }^{2}$

We summarize the firm characteristics in Table 1.

2 Institutional investors with more than $\$ 100$ million in equities must report their equity ownership to the SEC in quarterly 13-f filings. The CDA Spectrum classifies institutional investors of five types: bank (trust departments), insurance companies, investment companies (mutual funds and closed-end funds), independent investment advisors (principally pension fund advisors), and others (miscellaneous institutions such as endowment funds or public pension funds). 
Table 1. Summary statistics for firm characteristics.

\begin{tabular}{ccccccc}
\hline Statistics & SIZE & $\begin{array}{c}\text { Book-to-Market } \\
\text { (BM) }\end{array}$ & Runup & $\begin{array}{c}\text { Buy and Hold } \\
\text { Abnormal Return } \\
\text { (BHAR) }\end{array}$ & Over- & Debt \\
\cline { 2 - 7 } & & Ratio & (3 months) & (3 years) & Investment & Ratio \\
\hline Mean & 1468.35 & 0.298 & 0.185 & -0.170 & 0.023 & 0.215 \\
Median & 315.86 & 0.249 & 0.092 & -0.428 & 0.002 & 0.128 \\
Std & 7112.81 & 0.332 & 0.584 & 1.293 & 0.159 & 0.259 \\
Q1 & 134.04 & 0.121 & -0.087 & -0.843 & -0.052 & 0.004 \\
Q3 & 749.06 & 0.410 & 0.306 & 0.190 & 0.078 & 0.351 \\
\hline
\end{tabular}

This table provides summary statistics of SEO firms from 1990 to 2010 and the number of the company of SEOs is 1,400. The variables are defined as follows. Size is the natural log of the firm's market capitalization. BM ratio is the book-to-market ratio. Runup is the buy and hold abnormal return in three months before the SEOs. BHAR is the buy and hold abnormal return for three years after the SEOs. Over-investment is the capital expenditure over the expected level based on the estimation model in Richardson (2006). Debt ratio is the ratio of long-term debt to total assets.

From Table 1, we find that the long-term market performance, however, is poor in the SEO events, which is also consistent with the existing empirical evidence. Finally, the investment level is also above the expected level, which implies that these firms have aggressive investment strategies.

\subsection{Relative Measures}

We need measures to represent the characteristics of institutional holding, insider trading, and long-term market performance in the empirical tests. Hence, we summarize these measures as follows.

\subsubsection{Institutional Holding}

To measure the institutional holding, we use the number of shares held by institutions divided by the number of shares outstanding to calculate the percentage of institutional holdings.

\subsubsection{Insider Trading}

Previous studies measure insider trading in various ways. Gombola et al. (1997) and Gombola et al. (1999) observe the monthly number of insider transactions, number of shares, and dollar value around SEOs. Rozeff and Zaman (1998) employ insider trading deflated by trading volume (number of shares traded by insider over number of shares traded in the market) to investigate the direction of insider trades along the value/glamour spectrum. Lakonishok and Lee (2001) use the ratio of net insider trading (number of insider purchases minus number of insider sales) to total insider transactions over the past few months to examine the market reaction to insider trades. We use the number of net selling shares (number of shares sold minus number of shares bought) over the number of shares outstanding to measure the behavior of insider trading.

In order to capture the asymmetric reaction of insider trading, we decompose net selling into two components and create two variables to represent it. One is pnsh, the meaning of positive net selling when net selling is greater than zero and the other variable is nnsh, meaning of negative net selling when net selling is less than or equal to zero.

\subsubsection{Long-Term Market Performance}

We calculate buy-and-hold abnormal returns of a portfolio as follows:

$$
B H A R s_{p}=\frac{1}{N} \sum_{j=1}^{N}\left[\prod_{t=1}^{T}\left(1+R_{j, t}\right)-\prod_{t=1}^{T}\left(1+R_{\text {bench }, t}\right)\right]
$$


where $R_{j, t}$ and $R_{\text {bench, }}$, respectively, denote firm $j$ 's returns and benchmark returns on day $t$, and $N$ is the number of firms. We calculate return from the announcement date for these events and set a month to have 21 trading days. If the firm is delisted, returns are compounding until the delist date.

Finally, the Compustat database provides all the accounting data we need for capturing the firm characteristics. Following previous studies, we add firm characteristic variables in the regression analyses, which include over-investment (overinv), the MB ratio ( $\mathrm{mb}$ ), the firm size (size), the debt ratio (dr). We also control for year and industrial fixed effects in our regression analyses. Finally, to alleviate the effect of outliers in the following analysis, we winsorize all independent variables at $1 \%$ level.

\subsubsection{Empirical Models}

There are two parts to the empirical analyses in this study. First is the basic summary statistics for insider trading and the institutional holdings. We summarize the insider trades and the institutional holdings in the different time period before and after the SEOs. In the univariate analysis, we expect to observe the basic statistics of these two measures and check the systematic pattern of these two measures. Second, we perform the multivariate analysis by running the regressions of the level of institutional holdings and long-term market performance of SEO firms. In addition, we also apply the regression analysis on the spillover effect and check how the non-SEO firms react to the trading of insiders and institutional investors of SEO firms.

To test the first hypothesis, we summarize the basic statistics for the change of institutional holdings with respect to different insider trading in SEOs and check the statistics of the change of institutional holdings. We would get the primary results by checking the statistics. To check the robustness of our results, in the multivariate regression analyses, we run the regression of the institutional holdings on insider trades and control for all firm characteristics. The empirical model is as follows:

$$
\begin{aligned}
& \text { institutional holding } \\
& \qquad \begin{array}{l}
=\alpha+\beta_{1} \text { pnsh }+\beta_{2} \text { nnsh }+\beta_{3} \text { overinv }+\beta_{4} m b+\beta_{5} \text { size }+\beta_{6} d r \\
+
\end{array}
\end{aligned}
$$

where pnsh denote the positive insider net selling, nnsh is the negative insider net selling. In addition, we also control for industrial and year dummies in regression analyses.

Next, we measure the long-term market performance by three-year buy-and-hold abnormal return after SEOs and compare insider trading and the institutional holdings in the SEOs. We sort the long-term market reaction based on BHAR of different time periods and then summarize the statistics of the insider trading and the change of institutional holdings and analyze the pattern of these statistics. As in our previous analyses, we also perform the multivariate analysis of the long-term market reactions. The empirical model is:

$$
\begin{aligned}
\operatorname{BHAR}(0, t)= & \alpha+\beta_{1} \varepsilon_{\text {inst }}+\beta_{2} \text { pnsh }+\beta_{3} \mathrm{nnsh}+\beta_{4} \text { overinv }+\beta_{5} m b+\beta_{6} \text { size } \\
& +\beta_{7} d r+\beta_{8} \text { Runup }+\varepsilon,
\end{aligned}
$$

where $\varepsilon_{\text {inst }}$ is the residual of the institutional holding in the previous regression of institutional holdings. Based on the result of the first hypothesis testing, there may have endogenous problems because the insider trading may affect the change of institutional holdings. To alleviate the endogenous problem, we utilize two-stage least square in the regression analyses.

Finally, we test the spillover effect of insider trading and the change of institutional holding. To measure the spillover effect, we measure the insider trading and the change of institutional holdings for non-SEO firms. In the analysis of summary statistics, we check the basic statistics of insider trading and the change of institutional holdings for non-SEO firms. If there exists a spillover effect, then we would observe the consistent pattern of insider trading and the change of institutional holdings 
between event firms and rival firms in the same industry. In addition, we perform the multivariate regression analysis and the empirical models are follows:

$$
\begin{array}{ll}
\text { mholding }=\alpha & +\beta_{1} \text { pnsh }+\beta_{2} \text { nnsh }+\beta_{3} \text { overinv }+\beta_{4} m b+\beta_{5} \text { size }+\beta_{6} d r \\
& +\beta_{6} \text { Runup }+\varepsilon \\
\text { mholding }=\alpha \quad & +\beta_{1} \varepsilon_{\text {inst }}+\beta_{2} \text { pnsh }+\beta_{3} \text { nnsh }+\beta_{4} \text { overinv }+\beta_{5} m b+\beta_{6} \text { size } \\
& +\beta_{7} d r+\beta_{8} \text { Runup }+\varepsilon,
\end{array}
$$

where mholding is the institutional holdings of non-SEO firms. If the spillover effect exists, then we expect that the coefficients of $\beta_{1}$ and $\beta_{2}$ in Equation (4) and of $\beta_{1}, \beta_{2}$ and $\beta_{3}$ in Equation (5) would be significant.

\section{Empirical Results}

We analyze the institutional holdings before and after SEOs. The institutional holdings of four quarters before and after the events are summarized in Table 2.

Table 2. The median and mean of institutional holding.

\begin{tabular}{ccc}
\hline Quarter & Median & Mean \\
\hline-4 & 0.325 & 0.368 \\
-3 & 0.323 & 0.373 \\
-2 & 0.339 & 0.381 \\
-1 & 0.364 & 0.400 \\
1 & 0.524 & 0.518 \\
2 & 0.534 & 0.524 \\
3 & 0.529 & 0.526 \\
4 & 0.532 & 0.527 \\
\hline
\end{tabular}

The median of institutional holdings is calculated on a quarterly basis which is the frequency in the database. The effective date of each event is in Quarter 1 and the first quarter before the effective date is Quarter - 1. The number of the company of SEOs is 1,284 in Quarter 1.

From the results in Table 2, we find that the institutional investors increase their holdings substantially after SEOs, which implies that institutional investors do change their holdings after SEOs. Whether these changes are correlated with firms' operational performance is a key question about the information source of the information advantage for institutional investors. We summarize the operational performance in Table 3.

Table 3. The operational performance of sample firms.

\begin{tabular}{ccccccccc}
\hline \multirow{2}{*}{ Variable } & & \multicolumn{7}{c}{ Year } \\
\cline { 3 - 8 } & & $\mathbf{- 3}$ & $\mathbf{- 2}$ & $\mathbf{- 1}$ & $\mathbf{0}$ & $\mathbf{1}$ & $\mathbf{2}$ & $\mathbf{3}$ \\
\hline \multirow{2}{*}{ EBIT/Sales } & Median & 0.099 & 0.099 & 0.112 & 0.122 & 0.110 & 0.106 & 0.107 \\
& Mean & 0.023 & 0.027 & 0.035 & 0.045 & 0.038 & 0.032 & 0.030 \\
\multirow{2}{*}{ ROA } & Median & -0.013 & -0.046 & -0.056 & -0.016 & -0.040 & -0.050 & -0.012 \\
& Mean & -0.060 & -0.048 & -0.026 & 0.000 & -0.021 & -0.030 & -0.040 \\
\hline
\end{tabular}

We measure the firm's operational performance from EBIT/Sales and ROA. EBIT is the earnings before interest and taxes, ROA is the return on assets. The effective date is in year 0 and the median and mean of both measures are under annual basis. We collect the data for three years before and after the SEO events.

We find that the operational performance does not have an obvious improvement after the SEO events. The EBIT/sales improves in the current year of SEOs but gets back to the original level in the 
first year after SEOs. These results imply that institutional investors may not rely on the operational performance to adjust their holding of these sample firms.

Next, we check the change of holding of insiders. This may be another information source for institutional investors. We summarize the change of insider transactions in Table 4.

Table 4. The median and mean of insider transaction.

\begin{tabular}{ccccccc}
\hline \multirow{2}{*}{ Period } & \multicolumn{3}{c}{ Median } & \multicolumn{3}{c}{ Mean } \\
\cline { 2 - 6 } & Sell & Purchase & Net Sell & Sell & Purchase & Net Sell \\
\hline$(-6,-3)$ & 0.0002 & 0.0001 & 0.0000 & 0.0022 & 0.0008 & 0.0013 \\
$(-6,-2)$ & 0.0003 & 0.0001 & 0.0000 & 0.0025 & 0.0009 & 0.0016 \\
$(-6,-1)$ & 0.0003 & 0.0001 & 0.0001 & 0.0027 & 0.0010 & 0.0017 \\
$(-6,1)$ & 0.0027 & 0.0002 & 0.0018 & 0.0173 & 0.0014 & 0.0158 \\
$(-6,2)$ & 0.0027 & 0.0002 & 0.0016 & 0.0172 & 0.0015 & 0.0158 \\
$(-6,3)$ & 0.0027 & 0.0002 & 0.0016 & 0.0172 & 0.0015 & 0.0156 \\
$(-6,6)$ & 0.0030 & 0.0004 & 0.0016 & 0.0175 & 0.0019 & 0.0156 \\
$(-6,12)$ & 0.0038 & 0.0006 & 0.0018 & 0.0208 & 0.0024 & 0.0183 \\
$(-6,24)$ & 0.0047 & 0.0011 & 0.0023 & 0.0222 & 0.0035 & 0.0188 \\
$(-1,1)$ & 0.0025 & 0.0000 & 0.0020 & 0.0183 & 0.0009 & 0.0174 \\
\hline
\end{tabular}

We report the median and mean cumulative insider trading from month -6 to month $t$ relative to the SEO events. The number of observation is 1128. All numbers are a percentage of outstanding shares of all sample firms. Net sell is the difference between insider sell and insider purchase.

From Table 4, we find that insiders are in general reduce their holding before and after this event which implies that they do not expect better results after this specific event for the SEO firms. Even though the net sell increases before SEOs, the net sell substantially increases after the effective month. Based on these results, we suspect that insiders are pessimistic about the SEO events.

To analyze whether the insider transactions have a significant impact on the adjustment of institutional holding, we regress the institutional holdings on the net sell of insider transaction and control for other firm characteristics. The results are summarized in Table 5.

Table 5. The impact of insider trades on institutional holding.

\begin{tabular}{cccc}
\hline Variables & $\mathbf{( 1 )}$ & $\mathbf{( 2 )}$ & $\mathbf{( 3 )}$ \\
\hline pnsh & $-7.042^{* * *}$ & $-5.669^{* * *}$ & $-8.088^{* * *}$ \\
nnsh & $(0.003)$ & $(0.010)$ & $(0.001)$ \\
& $-15.163^{* *}$ & $-15.042^{* * *}$ & -1.255 \\
Over-investment & $(0.026)$ & $(0.037)$ & $(0.837)$ \\
Market-to-book (MB) & -0.004 & -0.003 & -0.049 \\
ratio & $(0.917)$ & $(0.947)$ & $(0.281)$ \\
& $0.095^{* * *}$ & 0.060 & 0.012 \\
size & $(0.016)$ & $(0.200)$ & $(0.811)$ \\
& $0.124^{* * *}$ & $0.108^{* * *}$ & $0.112 * * *$ \\
Debt ratio & $(0.000)$ & $(0.000)$ & $(0.000)$ \\
Runup & $0.212^{* * *}$ & $0.210^{* * * *}$ & $0.173 * *$ \\
& $(0.000)$ & $(0.000)$ & $(0.020)$ \\
Constant & -0.002 & -0.011 & -0.007 \\
& $(0.845)$ & $(0.283)$ & $(0.540)$ \\
Year dummy & $-0.346^{* * *}$ & $-0.295^{* * *}$ & $-0.274^{*}$ \\
Industry dummy & $(0.000)$ & $(0.027)$ & $(0.075)$ \\
Adjusted R-squared & No & Yes & Yes \\
\hline
\end{tabular}


We suspect that there is an asymmetrical impact of insider transaction on institutional holding, and therefore we create the variables of pnsh and nnsh from insider net sell of SEOs. Pnsh denotes the positive net sell of insider transactions when net sell is greater than zero, nnsh is the negative insider net sell of insider transactions when net sell is less than or equal to zero, and net sell is the difference between insider sell and insider purchase. The other variables of SEOs are defined as follows. MB ratio is the market-to-book ratio. Size is the natural log of the firm's market capitalization. Debt ratio is the ratio of long-term debt to total assets. Runup is the buy and hold abnormal return in three months before SEOs. Over-investment is the capital expenditure over the expected level based on the estimation model in Richardson (2006). The numbers in parentheses are robust p-values. ${ }^{* * *},{ }^{* *}{ }^{*}$ represent the significance under $1 \%, 5 \%, 10 \%$ level respectively.

The results in Table 5 support our expectation that the insider transactions have a significant impact on the adjustment of institutional holdings. Among the SEO events, institutional holdings decrease with the positive net sell of insider transaction. On the other hand, institutional holdings increase with the negative net sell of insider transaction. This result implies that insiders and institutional investors have the same point of views regarding SEOs.

Next, we analyse the impact of institutional investors or insider transaction on the firm's long-term market performance. The regression result is summarized in Table 6.

Table 6. The long-term performance of sample firms.

\begin{tabular}{cccc}
\hline Variables & $\mathbf{( 1 )}$ & $\mathbf{( 2 )}$ & $\mathbf{( 3 )}$ \\
\hline$\varepsilon_{\text {inst }}$ & 0.069 & 0.181 & 0.176 \\
pnsh & $(0.892)$ & $(0.745)$ & $(0.753)$ \\
& $-24.589^{* *}$ & $-19.172 * *$ & -6.108 \\
nnsh & $(0.010)$ & $(0.039)$ & $(0.632)$ \\
& 22.318 & -13.780 & -61.112 \\
Over-investment & $(0.545)$ & $(0.743)$ & $(0.359)$ \\
& 0.081 & -0.126 & -0.230 \\
MB ratio & $(0.755)$ & $(0.772)$ & $(0.634)$ \\
& 0.153 & -0.022 & -0.199 \\
size & $(0.542)$ & $(0.955)$ & $(0.727)$ \\
& 0.097 & 0.082 & 0.139 \\
Debt ratio & $(0.250)$ & $(0.407)$ & $(0.295)$ \\
& 0.639 & 0.337 & -0.047 \\
Runup & $(0.183)$ & $(0.549)$ & $(0.934)$ \\
& -0.052 & -0.076 & -0.104 \\
Constant & $(0.401)$ & $(0.197)$ & $(0.165)$ \\
& $-0.849 *$ & -0.535 & -0.413 \\
Year dummy & $(0.068)$ & $(0.377)$ & $(0.585)$ \\
\hline Industry dummy & No & Yes & Yes \\
Adjusted R-squared & No & No & Yes \\
\hline
\end{tabular}

The variables are defined as follows. The $\varepsilon_{\text {inst }}$ is the residuals of institutional holding in the regression analysis in Table 5 . Pnsh denotes the positive net sell of insider transaction of SEOs when net sell is greater than zero, nnsh is the negative insider net sell of insider transaction when net sell is less than or equal to zero, and net sell is the difference between insider sell and insider purchase of SEOs. MB ratio is the market-to-book ratio. Size is the natural log of the firm's market capitalization. Debt ratio is the ratio of long-term debt to total assets. Runup is the buy and hold abnormal return in three months before SEOs. Over-investment is the capital expenditure over the expected level based on the estimation model in Richardson (2006). The numbers in parentheses are robust p-values. ${ }^{* * *},{ }^{* *}$, * represent the significance under 1\%,5\%, 10\% level, respectively.

From Table 6, we find that insider transactions have more explanatory power than institutional holding in the SEO firms. The pnsh is significant with BAHR (3 years), but nnsh is not. In sum, 
we conclude that insider transactions have strong explanatory power to the long-term market performance while positive net sell of insider transactions regarding the SEOs. In contrast, the negative net sell of insider transactions is not.

Next, we check the change of holding of insiders of the matching firms. This may be another information source for institutional investors of the matching firms. We summary the change of insider transactions of the matching firms in Table 7.

Table 7. The median and mean of insider transaction of the matching firms.

\begin{tabular}{ccccccc}
\hline \multirow{2}{*}{ Period } & \multicolumn{3}{c}{ Median } & \multicolumn{3}{c}{ Mean } \\
\cline { 2 - 6 } & Sell & Purchase & Net Sell & Sell & Purchase & Net Sell \\
\hline$(-6,-3)$ & 0.0001 & 0.0000 & 0.0000 & 0.0031 & 0.0005 & 0.0026 \\
$(-6,-2)$ & 0.0001 & 0.0001 & 0.0000 & 0.0039 & 0.0006 & 0.0033 \\
$(-6,-1)$ & 0.0001 & 0.0001 & 0.0000 & 0.0035 & 0.0007 & 0.0029 \\
$(-6,1)$ & 0.0002 & 0.0001 & 0.0000 & 0.0047 & 0.0009 & 0.0038 \\
$(-6,2)$ & 0.0002 & 0.0001 & 0.0000 & 0.0047 & 0.0010 & 0.0037 \\
$(-6,3)$ & 0.0003 & 0.0001 & 0.0000 & 0.0048 & 0.0011 & 0.0037 \\
$(-6,6)$ & 0.0004 & 0.0002 & 0.0000 & 0.0047 & 0.0014 & 0.0034 \\
$(-6,12)$ & 0.0007 & 0.0003 & 0.0000 & 0.0058 & 0.0022 & 0.0036 \\
$(-6,24)$ & 0.0012 & 0.0007 & 0.0001 & 0.0080 & 0.0048 & 0.0032 \\
$(-1,1)$ & 0.0001 & 0.0000 & 0.0000 & 0.0035 & 0.0007 & 0.0028 \\
\hline
\end{tabular}

We report the median and mean cumulative insider trading from month -6 to month $t$ relative to the firms separately based on the matching firms of SEOs. All numbers are a percentage of outstanding shares of matching firms. Net sell is the difference between insider sell and insider purchase of the matching firms.

From Table 7, we find that insiders of the matching firms are in general reduce their holding before and after this event which implies that they do not expect better results after this specific event for the SEO firms.

Furthermore, we analyze the impact of insider transactions of SEOs on the institutional holding of the matching firms. The regression result is summarized in Table 8.

Table 8. The spillover effect of insider trades of SEOs.

\begin{tabular}{cccc}
\hline Variables & $\mathbf{( 1 )}$ & $\mathbf{( 2 )}$ & $\mathbf{( 3 )}$ \\
\hline pnsh & $-0.995^{* * *}$ & $-0.933^{* *}$ & $-0.889^{* *}$ \\
nnsh & $(0.004)$ & $(0.012)$ & $(0.024)$ \\
& $-9.311^{* *}$ & $-8.963^{*}$ & $-8.777^{*}$ \\
Over-investment & $(0.026)$ & $(0.053)$ & $(0.073)$ \\
& -0.009 & -0.019 & 0.002 \\
MB ratio & $(0.876)$ & $(0.736)$ & $(0.973)$ \\
& $0.090^{* * *}$ & $0.049^{* *}$ & $0.047^{*}$ \\
size & $(0.000)$ & $(0.014)$ & $(0.065)$ \\
& $0.055^{* * *}$ & $0.046^{* * *}$ & $0.052^{* * *}$ \\
Debt ratio & $(0.000)$ & $(0.000)$ & $(0.000)$ \\
& $0.084^{* * *}$ & 0.051 & $0.077^{*}$ \\
Runup & $(0.024)$ & $(0.190)$ & $(0.071)$ \\
& $0.031^{* * *}$ & $0.030^{* * *}$ & $0.032 * * *$ \\
Constant & $(0.003)$ & $(0.001)$ & $(0.001)$ \\
& 0.058 & $0.097^{*}$ & 0.058 \\
Year dummy & $(0.119)$ & $(0.097)$ & $(0.370)$ \\
Industry dummy & No & Yes & Yes \\
Adjusted R-squared & No & No & Yes \\
\hline
\end{tabular}


We suspect that there is an asymmetrical impact of insider transactions of SEOs on the institutional holding of matching firms, and therefore we create the variables of pnsh and nnsh from insider net sell of SEOs. Pnsh denotes the positive net sell of insider transaction of SEOs when net sell is greater than zero; nnsh is the negative insider net sell of insider transaction when net sell is less than or equal to zero; and net sell is the difference between insider sell and insider purchase of SEOs. The other variables of matching firms are defined as follows. MB ratio is the market-to-book ratio. Size is the natural log of the firm's market capitalization. Debt ratio is the ratio of long-term debt to total assets. Runup is the buy and hold abnormal return in three months before SEOs. Over-investment is the capital expenditure over the expected level based on the estimation model in Richardson (2006). The numbers in parentheses are robust p-values. ${ }^{* * *},{ }^{* *},{ }^{*}$ represent the significance under $1 \%, 5 \%, 10 \%$ level respectively.

The results in Table 8 support our expectation that the insider transactions of SEOs have a significant impact on the adjustment of institutional holdings of matching firms. Among the SEO events, the institutional holdings of matching firms decrease with the positive net sell of insider transactions of SEOs. On the other hand, the institutional holdings of matching firms increase with the negative net sell of insider transactions of SEOs. This result implies that institutional investors of matching firms and insiders of SEOs have the same point of views regarding SEOs.

Finally, we analyze the impact of the institutional holding of SEOs on the institutional holding of matching firms. The regression result is summarized in Table 9.

Table 9. The spillover effect of insider trades and institutional holding of SEOs.

\begin{tabular}{ccccc}
\hline Variables & $\mathbf{( 1 )}$ & $\mathbf{( 2 )}$ & $\mathbf{( 3 )}$ & $\mathbf{( 4 )}$ \\
\hline Iholding & $0.306^{* * *}$ & $0.231^{* * *}$ & $0.206^{* * *}$ & \\
& $(0.000)$ & $(0.000)$ & $(0.000)$ & $0.207^{* * *}$ \\
$\varepsilon_{\text {minst }}$ & & & $(0.000)$ \\
pnsh & & & 0.170 \\
nnsh & & & $(0.321)$ \\
& & & & 0.630 \\
Over-investment & 0.024 & 0.008 & 0.029 & $(0.808)$ \\
& $(0.655)$ & $(0.882)$ & $(0.617)$ & 0.021 \\
MB ratio & $0.066^{* * *}$ & $0.041^{*}$ & 0.036 & $0.719)$ \\
& $(0.000)$ & $(0.055)$ & $(0.204)$ & $(0.112)$ \\
size & $0.029^{* * *}$ & $0.028^{* * *}$ & $0.037^{* * *}$ & $0.053^{* * *}$ \\
& $(0.000)$ & $(0.000)$ & $(0.000)$ & $(0.000)$ \\
Debt ratio & $0.070^{*}$ & 0.051 & 0.067 & $0.081^{*}$ \\
& $(0.067)$ & $(0.192)$ & $(0.118)$ & $(0.055)$ \\
Runup & $0.035^{* * *}$ & $0.033^{* * *}$ & $0.035^{* * *}$ & $0.034^{* * *}$ \\
Constant & $(0.000)$ & $(0.000)$ & $(0.000)$ & $(0.000)$ \\
& $0.089^{* *}$ & $0.126^{* *}$ & 0.085 & 0.060 \\
Year dummy & $(0.014)$ & $(0.051)$ & $(0.223)$ & $(0.387)$ \\
Industry dummy & No & Yes & Yes & Yes \\
Adjusted & No & No & Yes & Yes \\
R-squared & 0.189 & 0.222 & 0.250 & 0.249 \\
\hline
\end{tabular}

The variables of shares holding are defined as follows. Iholding denotes the institutional holdings of SEOs. The $\varepsilon_{\text {minst }}$ is the residuals of the institutional holding of matching firms in the regression analysis in Table 8. Pnsh denotes the positive net sell of insider transactions of SEOs when the net sell is greater than zero; nnsh is the negative insider net sell of insider transaction when net sell is less than or equal to zero; and net sell is the difference between insider sell and insider purchase of SEOs. The other variables are defined as follows. MB ratio is the market-to-book ratio. Size is the natural log of the firm's market capitalization. Debt ratio is the ratio of long-term debt to total 
assets. Runup is the buy and hold abnormal return in three months before SEOs. Over-investment is the capital expenditure over the expected level based on the estimation model in Richardson (2006). The numbers in parentheses are robust p-values. ${ }^{* * *},{ }^{* *},{ }^{*}$ represent the significance under $1 \%, 5 \%, 10 \%$ level respectively.

From Table 9, we find that the institutional holdings of SEOs have a significant impact on the adjustment of institutional holdings of matching firms. Among the SEO events, the institutional holdings of matching firms increase or decrease in the same direction as the institutional holdings of SEOs. This result implies that institutional investors of matching firms and SEOs have the same point of views regarding SEOs.

\section{Conclusions}

In this study, we analyze three questions about the interaction between insider trades and institutional holdings in the major corporate SEO events. First, we test how insider trades affect the trading behavior of institutional investors in the SEOs. Second, due to the different characteristics of information sources, we test whose trading behavior, either insiders or institutional investors, has greater explanatory power for the performance of SEO firms after issuing new stocks. Third, in the SEOs, the insiders or institutional investors may signal some private information through their trading behaviors. How insiders and institutional investors of other non-SEO firms in the same industry react to these signals?

The empirical results show that the insider transactions have a significant impact on the institutional holdings. In the SEOs, institutional holdings change in the same direction as insider transactions. This result implies that insiders and institutional investors may have a similar point of view regarding the SEOs. Second, we find that insider transaction has greater explanatory power than institutional holdings for the long-term performance of the SEO firms after issuing new stocks. In sum, we conclude that institutional investors share similar information sources relative to insiders regarding the SEOs. In addition, the insider transaction has more explanatory power than institutional investors in the long-term market performance. Finally, among the SEO events, we also find that the institutional holdings of non-SEO firms change in the same direction with the insider trades and institutional holdings of SEO firms. This result implies that there exist spillover effects of insider trading and institutional holdings on those of non-SEO firms in the SEOs.

The main contribution of the research is to comprehensively analyze the reaction of insiders and institutional investors in the SEOs. In addition, through the analysis of the spillover effect of the SEOs, we can find how institutional investors of non-SEO firms react to the signals conveyed by insiders and institutional investors of SEO firms.

Author Contributions: C.-C.W. and T.-H.Y. conceived and designed the ideas. C.-C. collected the data and estimated the models. C.-C. and T.-H. analyzed the data and discussed the empirical results. C.-C. and T.-H. revised the paper.

Acknowledgments: We thank Jieran Wu and two anonymous reviewers for helpful comments.

Conflicts of Interest: The authors declare no conflict of interest.

\section{References}

Aboody, David, and Baruch Lev. 2000. Information asymmetry, R\&D, and insider gains. The Journal of Finance 55: 2747-66.

Akerlof, George A. 1970. The market for lemons: Quality uncertainty and the market mechanism. Quarterly Journal of Economics 84: 488-500. [CrossRef]

Aggarwal, Reena, Isil Erel, Miguel Ferreira, and Pedro Matos. 2011. Does governance travel around the world? Evidence from institutional investors. Journal of Financial Economics 100: 154-81. [CrossRef]

Baik, Bok, Jun-Koo Kang, and Jin-Mo Kim. 2010. Local institutional investors, information asymmetries, and equity returns. Journal of Financial Economics 97: 81-106. [CrossRef] 
Beatty, Anne, Scott Liao, and Jeff Jiewei Yu. 2013. The spillover effect of fraudulent financial reporting on peer firms' investments. Journal of Accounting and Economics 55: 183-205. [CrossRef]

Benveniste, Lawrence M., Walid Y. Busaba, and William J. Wilhelm Jr. 2002. Information externalities and the role of underwriters in primary equity markets. Journal of Financial Intermediation 11: 61-86. [CrossRef]

Benveniste, Lawrence M., Alexander Ljungqvist, William J. Wilhelm Jr., and Xiaoyun Yu. 2003. Evidence of information spillovers in the production of investment banking services. The Journal of Finance 58: 577-608. [CrossRef]

Bodnaruk, Andriy, Massimo Massa, and Andrei Simonov. 2009. Investment banks as insiders and the market for corporate control. Review of Financial Studies 22: 4989-5026. [CrossRef]

Bradley, Daniel, and Xiaojing Yuan. 2013. Information spillovers around seasoned equity offerings. Journal of Corporate Finance 21: 106-18. [CrossRef]

de Bruijn, Bert, and Philip Franses. 2018. How informative are earnings forecasts? Journal of Risk and Financial Management 11: 36. [CrossRef]

Chemmanur, Thomas J., Shan He, and Gang Hu. 2009. The role of institutional investors in seasoned equity offerings. Journal of Financial Economics 94: 384-411. [CrossRef]

Chiang, Raymond, and P. C. Venkatesh. 1988. Insider holdings and perceptions of information asymmetry: A note. The Journal of Finance 43: 1041-48. [CrossRef]

Darrough, Masako, and Srinivasan Rangan. 2005. Do insiders manipulate earnings when they sell their shares in an initial public offering? Journal of Accounting Research 43: 1-33. [CrossRef]

Dell'Ariccia, Giovanni, and Robert Marquez. 2004. Information and bank credit allocation. Journal of Financial Economics 72: 185-214. [CrossRef]

Eleswarapu, Venkat R., Rex Thompson, and Kumar Venkataraman. 2004. The impact of Regulation Fair Disclosure: Trading costs and information asymmetry. Journal of Financial and Quantitative Analysis 39: 209-25. [CrossRef]

Erwin, Gayle R., and James M. Miller. 1998. The intra-industry effects of open market share repurchases: Contagion or competitive? Journal of Financial Research 21: 389-406. [CrossRef]

Ferreira, Miguel A., and Pedro Matos. 2008. The colors of investors' money: The role of institutional investors around the world. Journal of Financial Economics 88: 499-533. [CrossRef]

Frankel, Richard, and Xu Li. 2004. Characteristics of a firm's information environment and the information asymmetry between insiders and outsiders. Journal of Accounting and Economics 37: 229-59. [CrossRef]

Gaspar, José-Miguel, Massimo Massa, and Pedro Matos. 2005. Shareholder investment horizons and the market for corporate control. Journal of Financial Economics 76: 135-65. [CrossRef]

Gleason, Cristi A., Nicole Thorne Jenkins, and W. Bruce Johnson. 2008. The contagion effects of accounting restatements. The Accounting Review 83: 83-110. [CrossRef]

Gombola, Michael, Lee Hei Wai, and Liu Feng-Ying. 1997. Evidence of selling by managers after seasoned equity offering announcements. Financial Management 26: 37-53. [CrossRef]

Gombola, Michael J., Hei Wai Lee, and Feng-Ying Liu. 1999. Further evidence on insider selling prior to seasoned equity offering announcements: The role of growth opportunities. Journal of Business Finance E Accounting 26: 621-49.

Griffin, John M., Tao Shu, and Selim Topaloglu. 2012. Examining the dark side of financial markets: Do institutions trade on information from investment bank connections? Review of Financial Studies 25: 2155-88. [CrossRef]

Hameed, Allaudeen, Randall Morck, Jianfeng Shen, and Bernard Yeung. 2015. Information, analysts, and stock return comovement. Review of Financial Studies 28: 3153-87. [CrossRef]

Harford, Jarrad. 2005. What drives merger waves? Journal of Financial Economics 77: 529-60. [CrossRef]

Harjoto, Maretno, and John Garen. 2005. Inside ownership beyond the IPO: The evolution of corporate ownership concentration. Journal of Corporate Finance 11: 661-79. [CrossRef]

Hsu, Hung-Chia, Adam V. Reed, and Jörg Rocholl. 2010. The new game in town: Competitive effects of IPOs. The Journal of Finance 65: 495-528. [CrossRef]

Hsu, Junming, Tung-Hsiao Yang, and Po-Shen Sung. 2016. SEO firms' lottery-like characteristics, institutional ownership, and long-run performance. Journal of Business Research 69: 2160-66. [CrossRef]

Huson, Mark R., and Gregory MacKinnon. 2003. Corporate spinoffs and information asymmetry between investors. Journal of Corporate Finance 9: 481-503. [CrossRef] 
Jegadeesh, Narasimhan, and Yue Tang. 2010. Institutional Trades around Takeover Announcements: Skill vs. Inside Information. SSRN Electronic Journal. Available online: https:/ / papers.ssrn.com/sol3/papers.cfm? abstract_id=1568859\# (accessed on 9 September 2018). [CrossRef]

Jiang, Hao. 2010. Institutional investors, intangible information, and the book-to-market effect. Journal of Financial Economics 96: 98-126. [CrossRef]

Jorion, Philippe, and Gaiyan Zhang. 2007. Good and bad credit contagion: Evidence from credit default swaps. Journal of Financial Economics 84: 860-83. [CrossRef]

Lakonishok, Josef, and Inmoo Lee. 2001. Are insider trades informative? Review of Financial Studies 14: 79-111. [CrossRef]

Luo, Yuanzhi. 2005. Do insiders learn from outsiders? Evidence from mergers and acquisitions. The Journal of Finance 60: 1951-82. [CrossRef]

Marquardt, Carol A., and Christine I. Wiedman. 1998. Voluntary disclosure, information asymmetry, and insider selling through secondary equity offerings. Contemporary Accounting Research 15: 505-37. [CrossRef]

Noe, Christopher F. 1999. Voluntary disclosures and insider transactions. Journal of Accounting and Economics 27: 305-26. [CrossRef]

Piotroski, Joseph D., and Darren T. Roulstone. 2004. The influence of analysts, institutional investors, and insiders on the incorporation of market, industry, and firm-specific information into stock prices. The Accounting Review 79: 1119-51. [CrossRef]

Richardson, Scott. 2006. Over-investment of free cash flow. Review of Accounting Studies 11: 159-89. [CrossRef]

Rozeff, Michael S., and Mir A. Zaman. 1998. Overreaction and insider trading: Evidence from growth and value portfolios. The Journal of Finance 53: 701-16. [CrossRef]

Shahrur, Husayn, and Anand Venkateswaran. 2009. Industry prospects and acquirer returns in diversifying takeovers. Journal of Financial Research 32: 23-51. [CrossRef]

Slovin, Myron B., Marie E. Sushka, and John A. Polonchek. 1992. Informational externalities of seasoned equity issues: Differences between banks and industrial firms. Journal of Financial Economics 32: 87-101. [CrossRef]

Song, Moon H., and Ralph A. Walkling. 2000. Abnormal returns to rivals of acquisition targets: A test of the acquisition probability hypothesis'. Journal of Financial Economics 55: 143-71. [CrossRef]

Wahal, Sunil, and John J. McConnell. 2000. Do institutional investors exacerbate managerial myopia? Journal of Corporate Finance 6: 307-29. [CrossRef]

Yang, Tung-Hsiao, Junming Hsu, and Wen-Ben Yang. 2016. Firm's motives behind SEOs, earnings management, and performance. International Review of Economics and Finance 43: 160-69. [CrossRef] 